\title{
Mechanical and Microstructural Properties of Ti-V-Al High Temperature Shape Memory Alloy
}

\author{
Semra Ergen ${ }^{1 *}$ \\ Gaziosmanpasa University, Faculty of Arts and Sciences, Department of Physics, Tokat, Turkey, (ORCID: 0000-0002-5515-0933), semraergengop@gmail.com
}

(3rd International Congress on Human-Computer Interaction, Optimization and Robotic Applications June 11-13, 2021)

(DOI: $10.31590 /$ ejosat.953551)

ATIF/REFERENCE: Ergen, S. (2021). Mechanical and Microstructural Properties of Ti-V-Al High Temperature Shape Memory Alloy. European Journal of Science and Technology, (26), 270-275.

\begin{abstract}
The phase transformation, microstructural and mechanical properties of Ti-15V-2Al high temperature shape memory alloy produced with arc-melting method were investigated by DSC, XRD, SEM and high temperature micro-indenter system. The reverse martensitic transformation $\mathrm{A}_{\mathrm{s}}$ starting and $\mathrm{A}_{\mathrm{f}}$ finishing temperatures of alloy were obtained to be $195{ }^{\circ} \mathrm{C}$ and $285{ }^{\circ} \mathrm{C}$, respectively. In high temperature microindentation analysis, the alloy were subjected to indentation tests under $5000 \mathrm{mN}$ load for three different temperatures $\left(24{ }^{\circ} \mathrm{C}, 250{ }^{\circ} \mathrm{C}\right.$ and $\left.450{ }^{\circ} \mathrm{C}\right)$. The hardness and reduced elastic modulus values of the alloy at room temperature $\left(24{ }^{\circ} \mathrm{C}\right)$, that is, martensite structure, were found to be higher than the values at $450{ }^{\circ} \mathrm{C}$, that is, austenite structure. The effect of temperature on superelasticity was examined and it was found that the superelasticity value of the alloy was higher at $450{ }^{\circ} \mathrm{C}$ compared to its value at $24^{\circ} \mathrm{C}$.
\end{abstract}

Keywords: Shape Memory Alloys, High Temperature, Mechanical Properties, Ti-Based Alloys, Superelasticity

\section{Ti-V-AI Yüksek Sıcaklık Şekil Hafızalı Alaşımın Mekaniksel ve Mikroyapısal Özellikleri}

$\ddot{O} z$

Ark eritme yöntemiyle üretilen Ti-15V-2Al yüksek sıcaklıklı şekil hafızalı alaşımın faz dönüşümü, mikroyapısal ve mekaniksel özellikleri DSC, XRD, SEM ve yüksek sıcaklık mikro çentme sistemi ile incelenmiştir. Alaşımın ters martensitik dönüşüm As başlangıç ve Af bitiş sıcaklıkları sırasıyla $195^{\circ} \mathrm{C}$ ve $285^{\circ} \mathrm{C}$ olarak elde edilmiştir. Yüksek sıcaklık mikro çentme analizlerinde, alaşım üç farklı sıcaklıkta $\left(24^{\circ} \mathrm{C}, 250{ }^{\circ} \mathrm{C}\right.$ ve $\left.450{ }^{\circ} \mathrm{C}\right) 5000 \mathrm{mN}$ yük altında çentik testlerine tabi tutulmuştur. Alaşımın oda sıcaklığında $(24$ ${ }^{\circ} \mathrm{C}$ ) yani martensit yapısındaki sertlik ve elastik modül değerlerinin, $450{ }^{\circ} \mathrm{C}$ 'deki yani östenit yapısındaki değerlerden daha yüksek olduğu tespit edilmiştir. Sıcaklığın süperelastisiteye etkisi incelenmiş ve alaşımın $450{ }^{\circ} \mathrm{C}^{\prime} \mathrm{deki}$ süperelastisite değerinin daha yüksek olduğu bulunmuştur.

Anahtar Kelimeler: Şekil Hafızalı Alaşım, Yüksek Sıcaklık, Mekaniksel Özellikler, Ti-Temelli Alaşımlar, Süperelastisite

\footnotetext{
*Corresponding Author: semraergengop@gmail.com; semra.ergen@gop.edu.tr
} 


\section{Introduction}

Shape memory alloys are a class of materials that increases rapidly the area of use at the world with progress of technology. It has a wide range of applications from textiles to healthcare, from the automotive industry to the defense industry and from medicine to the aerospace science industry [1-3]. The importance of shape memory alloys (SBA) or other name superalloys, especially in the aerospace industry, has been rapidly increasing in recent years [4]. The shape memory alloys to be used in the aerospace industry needs to have high transformation temperatures. Alloys with transformation temperatures above $100^{\circ} \mathrm{C}$ are known as high-temperature shape memory alloys [5]. Nowadays, shape memory alloys used for commercial purposes are mostly $\mathrm{Ni}-\mathrm{Ti}, \mathrm{Cu}$ and $\mathrm{Al}$ based alloy groups [6-9] and the transformation temperatures that activate the memory property of these alloys are generally below $100{ }^{\circ} \mathrm{C}$ [10-12].

In the aerospace industry, lightness as well as high transformation temperatures are also very important. The lightness of the materials to be used in aircraft and space vehicles will primarily provide fuel savings. In this context, it is important to produce and develop materials that have both light and high transformation temperature in the aerospace industry.

The transformation temperatures of Ti-V-Al alloys, whose densities are almost that of pure $\mathrm{Ti}(4.5 \mathrm{~g} / \mathrm{cm} \mathrm{3})$, are above 100 ${ }^{\circ} \mathrm{C}$. Therefore, it is a suitable material for use in aircraft engine. Because of their working environment, they will be exposed to both high temperature and many times deformations, so the mechanical properties at high temperatures of these alloys should be known. However, there are few studies on the mechanical properties of Ti-V-Al shape memory alloys at high temperatures under the indentation stress. As far as we know, there is no study other from our previous studies $[13,14]$. In the literature, the mechanical properties of Ti-based alloys have been investigated either at room temperature (RT) or their properties under tensile stress have been investigated by tensile test [15].

Dynamic micro-indenter technique is an analysis method used to determine the mechanical properties of materials [16]. The mechanical properties of Ti-V-Al alloy at RT (martensite), $250{ }^{\circ} \mathrm{C}$ (martensite + austenite) and $450{ }^{\circ} \mathrm{C}$ (austenite) can be determined by this analysis technique which can reach to high temperature.

In the present study, it was aimed to determine the mechanical properties (hardness and elastic modulus) and superelastisite at high temperatures $\left(250^{\circ} \mathrm{C}\right.$ ve $\left.450{ }^{\circ} \mathrm{C}\right)$ of the Ti$15 \mathrm{~V}-2 \mathrm{Al}$ shape memory alloy, which were designed for use in aircraft engine parts in the aerospace industry. From the microindentation analysis, it was determined that while the hardness and elastic modulus values were higher at $24{ }^{\circ} \mathrm{C}$ for Ti$15 \mathrm{~V}-2 \mathrm{Al}$, it showed better superelasticity at $450{ }^{\circ} \mathrm{C}$.

\section{Material and Method}

The Ti-15V-2Al (wt. \%) alloy was produced by arc-melting system under argon atmosphere in water-cooled copper crucible. In the sample production, pure Titanium, Vanadium and Aluminum (99.9\%, 99.99\% and 99.99\% respectively) were used. The alloy was melted at least four times to ensure homogenization. The arc-melted alloy was cut in plate form in the cutting device for analyses. Leaf-shaped ingots were sealed into a quartz tube under vacuum. After homogenizing at $900{ }^{\circ} \mathrm{C}$ for 8 hours, rapid cooling was do by dropping into ice water. The
DSC analyzes were performed to determine transformation temperatures. The microstructure of alloy with scanning electron microscopy (SEM) was examined. The crystal structure was determined by X-ray diffraction (XRD) analysis. The mechanical analyzes were performed at RT, $250^{\circ} \mathrm{C}$ and $450{ }^{\circ} \mathrm{C}$ with high temperature micro-indenter device.

\section{Results and Discussion}

The XRD graph of the Ti-15V-2Al alloy at RT is given in the Figure 1. From the diffraction pattern, it was observed that the alloy has an orthorhombic $\alpha^{\prime \prime}$ martensite phase and some $\beta$ phase remained unchanged in the structure.

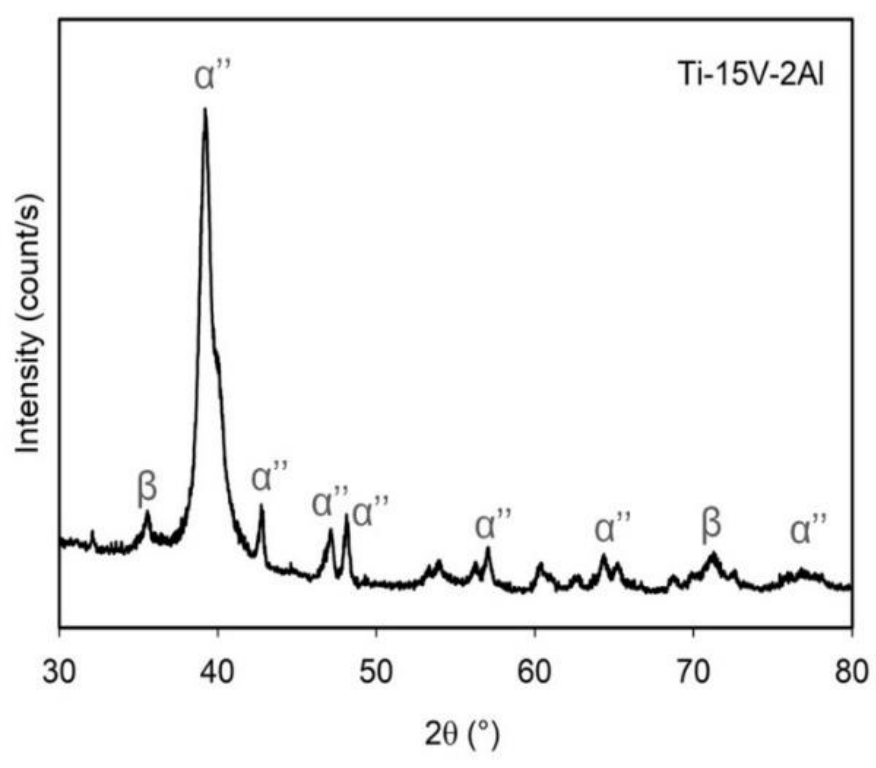

Fig 1. The XRD of the Ti-15V-2Al alloy

Figure 2 (a) shows the DSC curve of the Ti-15V-2Al alloy at a heating-cooling rate of $20{ }^{\circ} \mathrm{C} / \mathrm{min}$. During heating, the endothermic peak in the DSC curve represents the transition from an orthorhombic structure to a cubic structure, ie a reverse martensitic transformation. Reverse martensitic transformation temperatures were measured by tangent method according to DSC curves. The reverse martensitic transformation $\mathrm{A}_{\mathrm{s}}$ starting and $\mathrm{A}_{\mathrm{f}}$ finishing temperatures of alloy are $195^{\circ} \mathrm{C}$ and $285^{\circ} \mathrm{C}$, respectively (Table 1).

In the DSC analyzes of $\mathrm{Ti}-15 \mathrm{~V}-2 \mathrm{Al}$ alloy, while reverse martensitic transformation, endothermic peak, was observed during heating, exothermic peak representing martensitic transformation was not observed during cooling. This is attributed to the partial transformation of the $\beta$ phase to the $\alpha$ ", phase, to the fact that some $\beta$ phase remains unchanged in the structure or the DSC cannot be detected due to the low level of enthalpy of the transformation [17-20].

Figure 2(b) shows the thermal cycle analysis for the Ti-15V$2 \mathrm{Al}$ alloy at $20^{\circ} \mathrm{C} / \mathrm{min}$ heating and cooling rate. As seen from the graph, there was no important change was observed in the reverse martensitic transformation temperatures as the cycle number increased which means that the transformation is stable. 

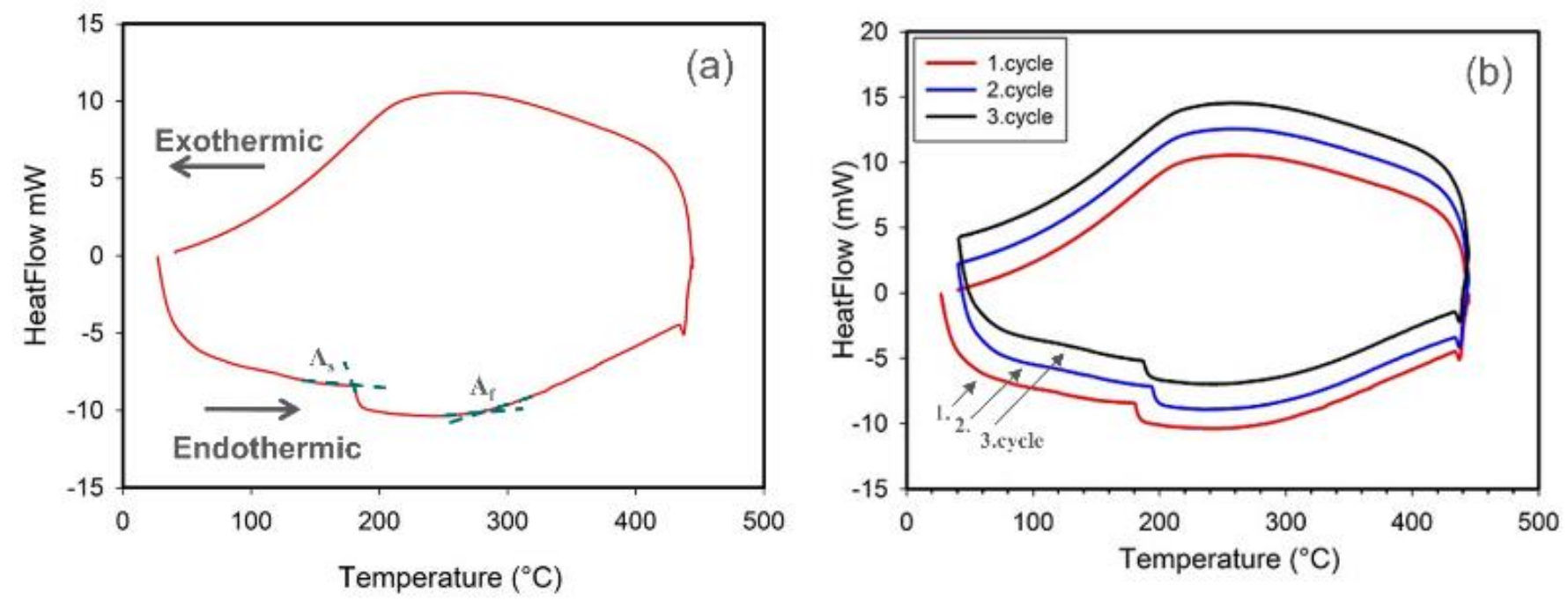

Fig 2. a ) The DSC curve and b) The cycle analysis of Ti-15V-2Al alloy at heating-cooling rate $20^{\circ} \mathrm{C} / \mathrm{min}$
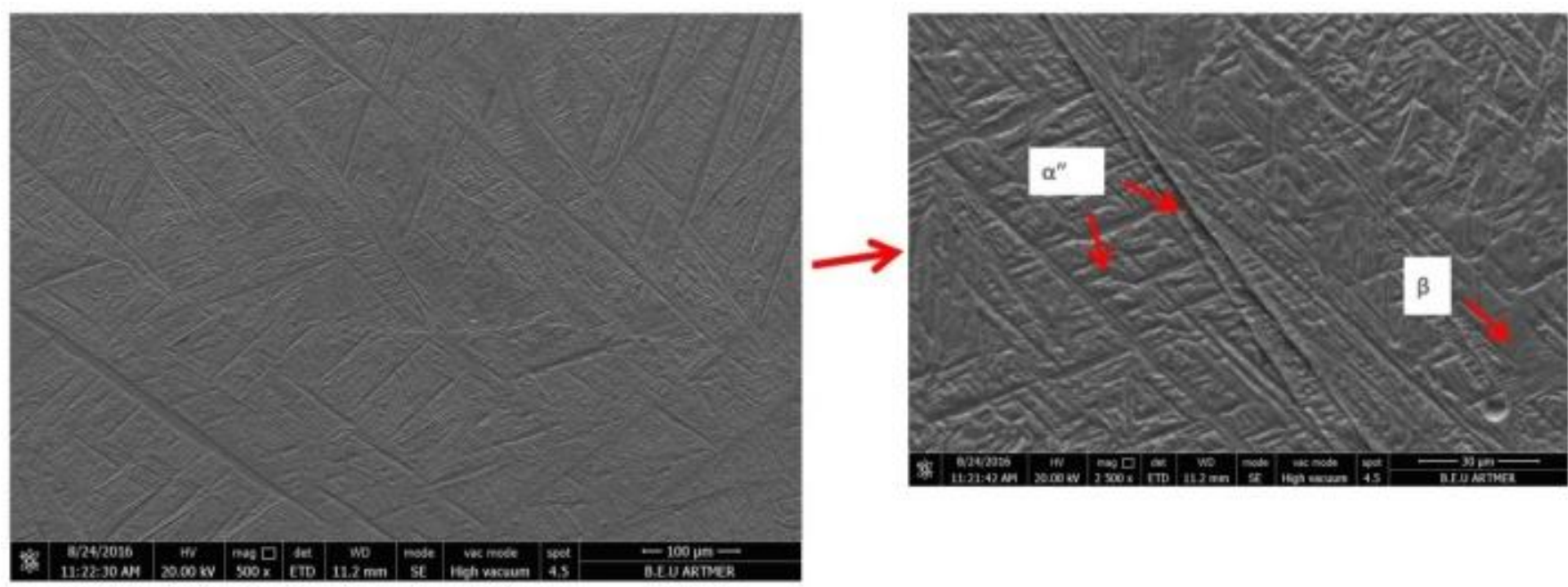

Fig. 3. SEM photographs of the Ti-15V-2Al alloy at 500 and 2500 magnification

Table 1. The transformation temperatures with the number of cycles at heating-cooling rate of $20^{\circ} \mathrm{C} / \mathrm{min}$

\begin{tabular}{|c|c|c|c|}
\hline $\begin{array}{c}\text { Heating Rate } \\
\left({ }^{\circ} \mathbf{C} / \mathbf{m i n}\right)\end{array}$ & $\begin{array}{c}\text { Cycle } \\
\text { Number }\end{array}$ & As $\left({ }^{\circ} \mathbf{C}\right)$ & Af $\left({ }^{\circ} \mathbf{C}\right)$ \\
\hline \multirow{2}{*}{20} & 1 & 195 & 285 \\
\cline { 2 - 4 } & 2 & 198 & 290 \\
\cline { 2 - 4 } & 3 & 196 & 288 \\
\hline
\end{tabular}

Table 2. The reduced elastic modulus and hardness values of the alloy at three different temperatures

\begin{tabular}{|c|c|c|c|}
\hline Sample & $\begin{array}{c}\text { Temperature } \\
\left({ }^{\circ} \mathbf{C}\right)\end{array}$ & $\begin{array}{c}\text { Hardness } \\
(\mathbf{G P a})\end{array}$ & $\begin{array}{c}\text { Reduced Elastic } \\
\text { Modulus (GPa) }\end{array}$ \\
\hline \multirow{3}{*}{ Ti-15V-2Al } & 24 & 5.94 & 121.8 \\
\cline { 2 - 4 } & 250 & 3.27 & 37.6 \\
\cline { 2 - 4 } & 450 & 4.51 & 59.5 \\
\hline
\end{tabular}



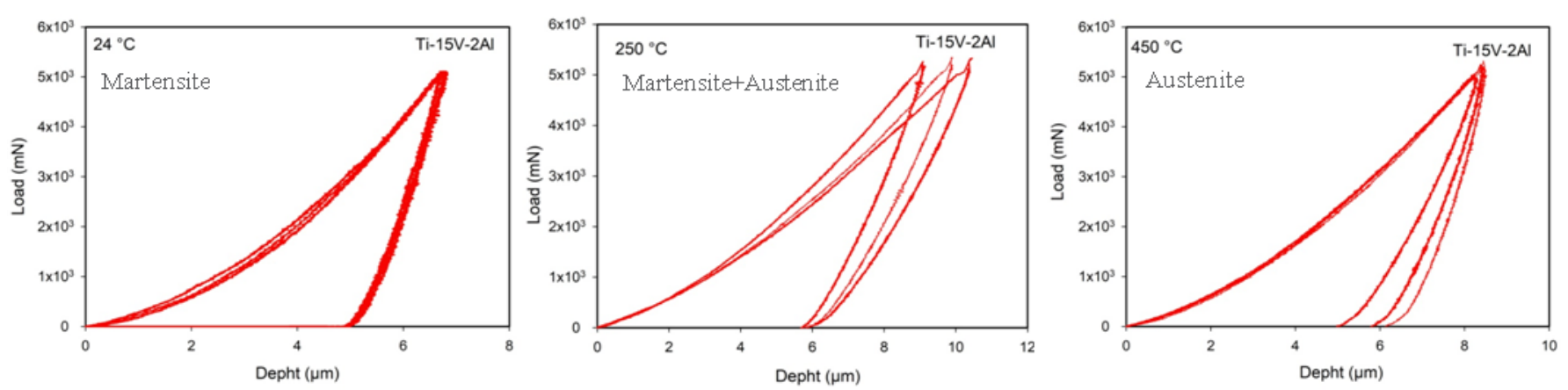

Fig. 4. Load-Unload curves of the alloy at $24^{\circ} \mathrm{C}, 250{ }^{\circ} \mathrm{C}$ and $450{ }^{\circ} \mathrm{C}$

Figure 3 shows SEM photographs of the alloy at 500 and 2500 magnification. In the microstructure of the alloy, it is seen that it contains $\beta$ phase as well as $\alpha$ " martensite phase. This result is in agreement with XRD analyzes. The acicular martensite structures and $\beta$ phase are indicated by arrows in Figure 3. In the microstructure analysis, it was determined that the alloy did not have a completely $\alpha$ " martensite structure at room temperature and that some $\beta$ phase remained unchanged in the structure.

Figure 4 shows the load-unload (LU) curves of the alloy. To determine the mechanical properties of the alloy, LU analysis were performed at temperatures RT, $250{ }^{\circ} \mathrm{C}$ and $450{ }^{\circ} \mathrm{C}$. The overlap of the LU curves means that the microstructure is homogeneous $[21,22]$. The LU curves of the alloy at RT and 450 ${ }^{\circ} \mathrm{C}$ appear to overlap almost. However, there is no overlap in LU analysis at $250{ }^{\circ} \mathrm{C}$. The alloy consists of martensite twinning at RT and $\beta$ phase at $450{ }^{\circ} \mathrm{C}$. At $250{ }^{\circ} \mathrm{C}$, it has two different phases. At each LU analysis, indent corresponds to a different phase (martensite or austenite) so the curves do not overlap.

The Figure 5 (a) shows change with temperature of the reduced elastic modulus and hardness values obtained from the LU curves for the Ti-15V-2Al alloy. Table 2 gives the reduced elastic modulus and hardness values of alloy. As seen in Figure 5(b), these values are higher at room temperature (martensite) than at $450{ }^{\circ} \mathrm{C}$ (austenite). This means that the martensite phase, also known as the low temperature phase, is harder than the austenite phase; ie high temperature phase.
Hardness is a measure of the resistance of the material against deformation. The reason of the higher hardness value in the martensite structure can be explained by the deformationpreventing effects of the twinning forming the martensite structure. It was detected that the elastic modulus values and hardness of the Ti-12V-4Al alloy obtained in our previous study were similar to those of the Ti-15V-2Al alloy for both phase structures [14].

On the contrary, when compared with the Ti-15V-4Al- $-0.5 \mathrm{Cu}$ alloy, it was determined that the hardness and elastic modulus value at $450{ }^{\circ} \mathrm{C}$ were much lower than the present study [13].

In Figure $5(\mathrm{~b})$, the variation of superelasticity values $\left(\eta_{\mathrm{SE}}\right)$ calculated from the equation 1 depending on temperature is given [23]. The SE represents superelasticity of alloy and hc, hf, hmaks are contact depth maximum depth, final depth, respectively. The superelasticity of the alloy, which has an austenite phase at $450{ }^{\circ} \mathrm{C}$, is higher than the martensite structure at $24{ }^{\circ} \mathrm{C}$. This is associated with the formation or reorientation of martensite twin structures and it is explained as follows.

The alloy contains martensite at $24{ }^{\circ} \mathrm{C}$ and some austenite. Stress induced martensite plates may form in the austenite when the load is applied. When the load is removed, the recycling of these martensite structures is prevented by the existing martensites and the stress value required for recycling increases. A higher stress value causes a decrease in superelasticity [4, 24].
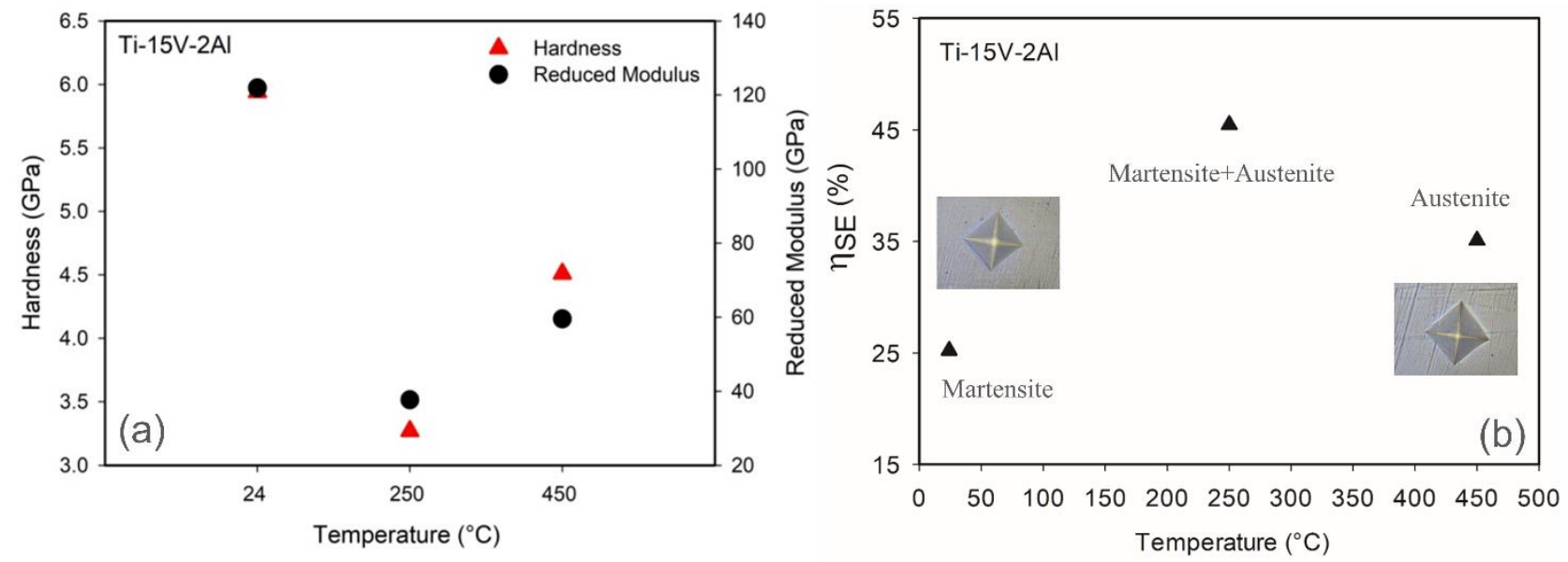

Fig. 5. a) Hardness and reduced elastic modulus and b) Superelastisity values depending on temperature 
At $450{ }^{\circ} \mathrm{C}$, the alloy has the austenite phase and stress induced martensite formed under stress are more easily recycled when the applied force is removed and thus superelasticity is increased.

$$
\eta_{S E}=\frac{h c-h f}{h m} x 100
$$

Since the alloy does not complete the austenite transformation at $250{ }^{\circ} \mathrm{C}$, both austenite and martensite phases are present in the structure. Superelasticity varies in relation to the martensite and austenite volume fraction formed in the structure.

But we do not have information about the volume fraction of the both phases at $250{ }^{\circ} \mathrm{C}$. Therefore, change in superelasticity value calculated at $250{ }^{\circ} \mathrm{C}$ cannot be explained in detail. For a more detailed study, simultaneous TEM analyzes under stress are required, which can be do in rare centers all over the world. The optical photographs given in Figure 5 (b) belong to the traces formed in the structure after indentation at $24{ }^{\circ} \mathrm{C}$ and $450{ }^{\circ} \mathrm{C}$. The traces appears rectangular shape due to the tip geometry with the Vickers indentation. Superelasticity values were found to be better than the results obtained in our other studies for both martensite and austenite phases. It is thought that this situation is caused by martensite twin orientations, which are affected by the change of $\mathrm{V}, \mathrm{Al}$ contents.

\section{Conclusions and Recommendations}

In this study, high temperature mechanical properties, thermal cycling analysis, microstructure and phase transformation of Ti-15V-2Al alloy were investigated. The results are summarized below.

1. In the microstructure of $\mathrm{Ti}-15 \mathrm{~V}-2 \mathrm{Al}$ alloy at room temperature, it was determined that there was some $\beta$ phase as well as orthorhombic $\alpha$ ' martensite phase.

2. At heating-cooling of $20^{\circ} \mathrm{C} / \mathrm{min}$, reverse martensitic transformation temperatures (As and Af) were found to be $195{ }^{\circ} \mathrm{C}$ and $285{ }^{\circ} \mathrm{C}$, respectively. No exothermic pike was found for the $\mathrm{Ti}-15 \mathrm{~V}-2 \mathrm{Al}$ alloy while being cooled from $500{ }^{\circ} \mathrm{C}$ to room temperature.

3. Depending on the number of thermal cycles, no significant change in reverse martensitic transformation temperatures was observed which means that the transformation is stable.

4. The hardness values of the alloy were 5.94, 3.27 and $4.51 \mathrm{GPa}$, and the values of the reduced elastic modulus were found as $121.8,37.6$, and $59.5 \mathrm{GPa}$ at $\mathrm{RT}, 250^{\circ} \mathrm{C}$ and $450{ }^{\circ} \mathrm{C}$, respectively. As a result of the mechanical analysis, martensitic structure at RT was found to be harder than the austenite structure at $450{ }^{\circ} \mathrm{C}$.

5. It was determined that the superelastic behavior of the alloy was better at $450{ }^{\circ} \mathrm{C}$ than at $24{ }^{\circ} \mathrm{C}$.

When all the results are evaluated, it can be concluded that the alloy is preferable for high temperature applications.

\section{References}

1. G.S. Firstov, J. Van Humbeeck, Y.N. Koval," Hightemperature shape memory alloys, some recent developments," Mater. Sci. Eng. A, 378, 2-10, 2004.

2. O. Ozbulut, S. Daghash, M. Sherif," Shape memory alloy cables for structural applications," J. Mater. Civ. Eng., 28(4), 04015176, 2015.

3. J.V. Humbeeck," High temperature shape memory alloys," Engineering Materials and Technology, 121, 4, 1999.

4. J. Ma, I. Karaman and R.D. Noebe," High temperature shape memory alloys," International Material Reviews, 55: 5, 257-315, 2010.

5. K.C. Atl, I. Karaman, R.D. Noebe, A. Garg, Y.I. Chulyakov, I.V. Kireeva, "Shape memory characteristics of $\mathrm{Ti}_{49.5} \mathrm{Ni}_{25} \mathrm{Pd}_{25} \mathrm{Sc}_{0.5}$ high-temperature shape memory alloy after severe plastic deformation," Acta Mater., 59, 4747 4760, 2011.

6. X.L. Meng, W. Cai, L.M. Wang, Y.F. Zheng, L.C. Zhao, L.M. Zhou, "Microstructure of stress-induced martensite in a Ti-Ni-Hf high temperature shape memory alloy," Scripta Mater, 45, 1177-1182, 2001.

7. H. Kato, R. Stalmans, J. Van Humbeeck," Two-way shape memory effect induced by tension training in $\mathrm{Cu}$ 13.4Al4.0Ni (mass\%) alloy single crystals," Mater. Trans., 39, 378-386, 1998.

8. X.H, Zheng, J.H. Sui, X. Zhang, Z.Y. Yang, H. B. Wang, X.H. Tian, W. Cai," Thermal stability and high-temperature shape memory effect of Ti-Ta-Zr alloy," Scripta Mater, 68, 1008-1011, 2013.

9. K. Otsuka, K.M. Wayman, J. Van Humbeeck, R. Stalmans, "Characteristics of Shape Memory Alloys," Cambridge University Press., p. 149, Cambridge, 1999.

10. K. Otsuka, X. Ren," Physical metallurgy of Ti-Ni-based shape memory alloys," Prog. Mater. Sci., 50, 511-678, 2005.

11. B. Kochar, I. Karaman, J.I. Kim, Y. I. Chumlyakov, J. Sharp," Thermo-mechanical cyclic response of an ultra fine grained NiTi shape memory alloy," Acta Mater,56, 3630 3646, 2008.

12. P.J.S. Buenconsejo, H.Y. Kim, H. Hosoda, S. Miyazaki, "Shape Memory Behavior of Ti-Ta and Its Potential as High Temperature Shape Memory Alloy,” Acta Mater., 57, 10681077, 2009.

13. S. Ergen, "The effect of indentation temperature and load on mechanical characterization and transformation behavior of high temperature Ti-V-Al-Cu shape memory alloy," Materials Chemistry and Physics, 268, 124757, 2021.

14. O. Bağ, F. Yılmaz, U. Kölemen, S. Ergen, C. Temiz, O. Uzun, "Transformational, microstructural and superelasticity characteristics of $\mathrm{Ti}-\mathrm{V}-\mathrm{Al}$ high temperature shape memory alloys with Zr addition," Phys. Scr., 96, 085702, 2021.

15. M. Hiroaki, Y. Hiroshi, F. Damien, M. Eric, C. Akihiko, G. Fumihiko, "Mechanical behaviors of Ti-V- (Al, Sn) alloys with martensite microstructure," Journal of Alloys and Compounds, 509, 2684-2692, 2011.

16. O. Uzun, N. Basman, C. Alkan, U. Kölemen, F. Y1lmaz,” Depth sensing indentation analysis of electrochemically synthesized polythiophene," Materials Chemistry and Physics, 124, 196-202, 2010. 
17. Y. Cui, Y. Li, K. Luo, H. Xu, "Microstructure and shape memory effect of Ti-20Zr-10Nb alloy," Mat. Sci. Eng. A.,527, 652-656, 2010.

18. E. Takahashi, T. Sakurai, S. Watanabe, N. Masahashi, S. Hanada," Effect of heat treatment and Sn content on superelasticity in biocompatible TiNbSn alloy," Mater. Trans. ,43, 12, 2978-2983, 2002.

19. X.H. Zheng, J. H. Su, X. Zhang, X.H. Tian, W. Cai,” Effect of $Y$ addition on the martensitic transformation and shape memory effect of Ti-Ta high-temperature shape memory alloy," Journal of Alloys and Compounds, 539, 144- 147, 2012.

20. O. Bağ, S. Ergen, F. Yılmaz, U. Kölemen,” Influence of Al content on transformation temperature and activation energy of Ti-V-Al high temperature shape memory alloys," Solid State Communications, 323, 114104, 2021.

21. F. Yılmaz, O. Uzun, U. Kölemen, M.F. Kılıcaslan, N. Basman, S. Ergen, K. Ozturk, E. Yanmaz," Nanoindentation study on Gd-deposited $\mathrm{YBaCuO}$ superconductor," Bull. Mater. Sci., 36, 7, 1139-1145, 2013.

22. O. Uzun, F. Yılmaz, U. Kölemen, N. Basman,” Sb effect on micro structural and mechanical properties of rapidly solidified Al-12Si alloy," Journal of Alloys and Compounds, 509, 21-26, 2011.

23. F. Khaleghi, M. Tajally, E. Emadoddin and M. Mohri," The investigation of the mechanical properties of graded hightemperatureshape memory Ti-Ni-Pd alloy," J. Alloys Compd., 787, 882-92, 2019.

24. X. Yi, B. Sun, W. Gao, X. Meng, Z. Gao, W. Cai and L. Zhao, "Microstructure evolution and superelasticity behaviorofTi-Ni-Hfshapememory alloy composite with multi-scale and heterogeneous reinforcements," Journal of Materials Science \& Technology, 42, 113-21, 2020. 